\title{
PENDAMPINGAN MEMBUAT POP UP BOOK MACE (MEMBACA ASYIK DAN CERIA) SEBAGAI UPAYA MENINGKATKAN LITERASI ANAK AUTISME DI SLB ANIM HA
}

\author{
Anis Munfarikhatin ${ }^{*}$ \\ Rachmat ${ }^{2}$ \\ 1,2 Universitas Musamus, Indonesia \\ munfarikhatin fkip@unmus.ac.id ${ }^{*}$ ) \\ rachmat@unmus.ac.id ${ }^{2)}$
}

Kata Kunci: [Pop up

book, Literasi, Autisme]

\begin{abstract}
Abstrak: Kegiatan pengabdian ini berupa pendampingan membuat pop up book yang terintegrasi dengan budaya lokal papua yang bertujuan untuk meningkatkan literasi anak autisme di SLB Negeri Anim Ha. Metode kegiatan meliputi empat tahapan yaitu tahap persiapan, tahap pengenalan, tahap pengkapasitasan, dan tahap penerapan. Tahap persiapan meliputi pembuatan sampel, video tutorial dan pendataan peserta pendampingan. Tahap pengenalan meliputi pengenalan alat dan bahan serta perangkat lunak yang digunakan. Tahap pengkapasitasan meliputi pemilihan konten pop up book Mace, mendesain sketsa pop up book Mace pada kertas, menyusun dan mempresentasikan pop up book Mace. Tahap penerapan yaitu menerapkan pop up book Mace yang telah dibuat ke anak autis. Hasil capaian peserta pendampingan adalah meningkatnya pengetahuan peserta dengan rata-rata lebih dari $60 \%$ pada setiap kegiatan pokok. Manfaat yang dirasakan oleh peserta diantaranya peserta mampu dan terampil dalam membuat media pembelajaran berupa pop up book Mace yang sesuai untuk melatih fokus anak berkebutuhan khusus yaitu autisme. Dari pelaksanaan kegiatan dapat disimpulkan bahwa pendampingan dalam membuat media pembelajaran perlu dikembangkan media yang inovatif dan memiliki visualisasi yang menarik khususnya bagi anak berkebutuhan khusus autisme. Olehkarena itu peran guru khususnya keterampilan dalam menyusun media tersebut sangat diperlukan.
\end{abstract}

Published by:

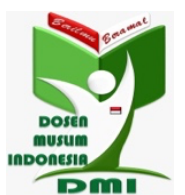

Copyright (C) 2021 The Author(s)

This article is licensed under CC BY 4.0 License

(cc) BY

https://dmi-journals.org/jai/ 


\section{Pendahuluan}

Teori humanistik menyatakan bahwa pendidikan merupakan suatu kegiatan memanusiakan manusia. Dengan kata lain pendidikan memberikan kesempatan yang sama kepada manusia tanpa memandang kelebihan dan kekurangan masing-masing. Di Indonesia pendidikan yang sering menjadi sorotan adalah pendidikan formal dari jenjang SD, SMP, dan SMA serta Universitas. Media pembelajaran, metode, model maupun strategi pembelajaran lebih banyak dikembangkan dan disoroti. Bukan hanya siswanya tetapi guru-guru maupun para pendidik di jenis pendidikan ini memiliki porsi lebih dalam perspektif dunia pendidikan. Pendidikan Luar Biasa (PLB) seharusnya juga memiliki kesejajaran dalam hal yang sama di dunia pendidikan. Metode maupun treatmen yang diberikan untuk siswa berkebutuhan khusus perlu dikembangkan sesuai dengan tipe dan karakteristik siswa. PLB merupakan pendidikan yang memfasilitasi anak-anak berkebutuhan khusus atau gangguan mental (mental disorder) dari jenjang SDLB (Sekolah Dasar Luar Biasa), SMPLB (Sekolah Menengah Pertama Luar Biasa) dan SMALB (Sekolah Menengah Atas Luar Biasa).

Salah satu gangguan mental (mental disorder) yang banyak dijumpai adalah autisme. Autisme merupakan suatu gangguan dalam perkembangan yang berpengaruh pada gangguan komunikasi verbal, non verbal, serta interaksi sosial (Winarno, 2013)(Maulana \& Rahayu, 2020). Anak-anak penderita autisme pada dasarnya memiliki kesulitan dalam berkomunikasi terutama masalah bahasa, berbicara dan berinterakasi dengan orang lain (Depa Nursita, Lukman Hamid, 2020). Permasalahan tersebut dapat ditangani dengan media yang tepat terutama media untuk melatih fokus atau konsentrasi untuk siswa autisme. Salah satu terapi yang bisa digunakan adalah dengan terapi visual (Martono, Eridani, \& Isabella, 2020). Visualisasi objek berupa objek-objek tiga dimensi yang dikemas dalam bentuk bacaan dalam buku sesuai dengan karakeristik siswa autisme, selain bisa melatih fokusnya juga dapat meningkatkan kemampuan literasinya dengan bantuan objek-objek tiga dimensi tersebut sehingga pembiasaan dalam berliterasi juga dapat dilakukan.

Peran guru dalam hal menangani anak autis sangat penting, sehingga diperlukan suatu pendampingan dalam menyusun suatu strategi, metode maupun media yang sesuai untuk melatih konsentrasi dan meningkatkan literasi siswa autis. Pentingnya literasi telah digiatkan oleh Menteri Pendidikan dan Kebudayaan sejak tahun 2016 sebagai bagian dari peraturan Nomor 23 tahun 2015 dalam menumbuhkan budi pekerti diantaranya menjadikan sekolah sebagai tempat yang menyenangkan, menumbuhkembangkan kebiasaan yang baik dan pendidikan karakter, menjadikan pendidikan sebagai kegiatan yang melibatkan berbagai pihak, menumbuhkembangkan lingkungan dan budaya belajar yang serasi antara sekolah, keluarga dan masyarakat melalui Gerakan Literasi Sekolah (GLS) khususnya bagi anak berkebutuhan khusus autisme.

Minimnya literasi siswa pada masa sekarang dipengaruhi oleh beberapa faktor diantaranya kurangnya buku-buku berkualitas yang ada di Indonesia dan kurangnya keterlibatan masyarakat dalam mendukung program pemerintah. Literasi yang ditekankan oleh mendikbud diantaranya adalah literasi membaca, literasi matematika dan literasi sains. Proses berliterasi lebih bermakna apabila dikaitkan dengan budaya setempat atau kearifan lokal daerah khususnya Merauke. (Yuliani, 2020) mengemukakan kearifan lokal sebagai pengetahuan setempat yang menjadi dasar identitas kebudayaan. 
Kearifan lokal dapat meliputi bahasa, kebiasaan, sudut pandang, ikon daerah, dan sebagainya yang menjadi ciri khas suatu daerah tertentu.

Papua merupakan salah satu propinsi di Timur Indonesia terkenal akan budayanya yang unik dan beragam dan di sinilah terdapat kabupaten dengan letak paling ujung timur Indonesia yaitu Merauke. SLB Negeri Anim Ha merupakan satu-satunya SLB di kabupaten Merauke yang meliputi pendidikan luar biasa pada jenjang sekolah dasar, sekolah menengah pertama dan sekolah menengah atas. Jumlah guru dan tenaga pekerja di sekolah ini sangat minim, bahkan sebagian besar bukan lulusan dari Pendidikan Luar Biasa (PLB). Jumlah guru dari semua jenjang adalah 32 guru dengan jumlah siswa lakilaki 63 dan perempuan 52. Jumlah siswa pengidap autisme sebanyak 28 siswa. SLB Negeri Anim Ha berlokasi di Jalan Biankuk Kelurahan Karang Indah Kecamatan Merauke Kabupaten Merauke. Para guru mejelaskan belum pernah ada pelatihan khusus bagi guru SLB dalam membuat suatu media pembelajaran bagi anak autisme yang dirancang khusus untuk melatih fokus mereka. Dengan adanya pandemi Covid 19 juga semakin memperburuk keadaan. Hal ini disikapi sekolah dengan meminjamkan buku maupun media pembelajaran yang digunakan secara bergantian karena dinilai lebih efektif.

Berdasarkan paparan analisis situasi maka permasalahan mitra diantaranya kurangnya pemahaman guru terhadap media pembelajaran untuk anak autis, belum adanya pelatihan untuk meningkatkan keterampilan guru dalam mendesain media pembelajaran anak autis, belum adanya integrasi kearifan lokal dalam media pembelajaran anak autis, belum adanya media pembelajaran untuk meningkatkan kemampuan literasi siswa autis.

\section{Metode Pelaksanaan}

Kegiatan pengabdian dalam bentuk pendampingan dilaksanakan di SLB Negeri Anim Ha yang berlokasi di Jalan Biankuk Kelurahan Karang Indah Kota Merauke. Sebanyak 20 guru dari semua jenjang di SLB dilibatkan menjadi peserta pendampingan dengan pertimbangan karena setiap jenjang di sekolah tersebut terdapat anak pengidap autis. Secara garis besar pelaksanaan pengabdian yang berupa pendampingan ini ada empat tahapan utama yaitu persiapan, pengenalan, pengkapasitasan dan penerapan. Proses alur tahapan tersebut digambarkan pada Gambar 1 berikut.

\begin{tabular}{c|l}
$\begin{array}{c}\text { Tahap } \\
\text { Persiapan }\end{array}$ & $\begin{array}{l}\text { 8. Membuat sampel pop up book Mace } \\
\text { 9. Membuat video tutorial pop up book Mace } \\
\text { 10. Pendataan peserta pendampingan }\end{array}$ \\
Tahap & $\begin{array}{l}\text { 1. Pengenalan alat dan bahan yang digunakan } \\
\text { Pengenalan }\end{array}$ \\
$\begin{array}{l}\text { 2. Pengenalan dan penjelasan perangkat lunak yang } \\
\text { digunakan }\end{array}$ \\
Tahap
\end{tabular}




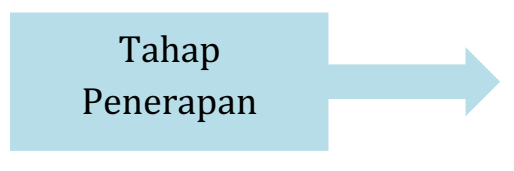

11. Penerapan pop up book Mace kepada siswa autisme di SLB Anim Ha Merauke

Gambar 1. Alur Kegiatan Pendampingan

\section{Tahap Persiapan}

Pada tahap ini dilakukan hal- hal yang harus disiapkan sebelum dilakukan kegiatan pendampingan diantaranya membuat sampel pop up book Mace oleh tim, pembuatan video tutorial untuk memudahkan peserta dalam memahami perosedur pop up book Mace dan melakukan pendataan peserta pendampingan.

\section{Tahap Pengenalan}

Tim pengabdian mengenalkan alat dan bahan serta kegunaannya dalam pembuatan pop up book Mace dan perangkat lunak yang akan digunakan untuk mendesain.

\section{Tahap Pengkapasitasan}

Kegiatan pengkapasitasan meliputi kegiatan pemilihan konten literasi membaca, matematika dan sains. Konten pada literasi membaca akan diarahkan pada pembuatan pop up book dengan cerita rakyat daerah maupun kearifan lokal lain. Konten pada matematika dirahkan untuk membuat siswa paham tentang bangun ruang dan bendabenda menyerupai bangun ruang, konsep bilangan bulat dan logika dasar yang diintegrasikan dengan budaya lokal. Konten pada sains dapat dikembangkan mengenai alam sekitar dan sesuai dengan kreatifitas peserta pendampingan yang tentunya diintegrasikan dengan budaya lokal. Selanjutnya membuat sketsa kasar pop up book Mace pada kertas, dengan tujuan supaya pop up book Mace lebih terstruktur. Berikutnya adalah mendesain karakter Mace yang menjadi ikon pop up book menggunakan perangkat lunak. Berikutnya adalah menyusun potongan-potongan hasil desain yang sudah dicetak kemudian ditempelkan pada buku sehingga menjadi buku tiga dimensi. Tahapan terakhir dari kegiatan pengkapasitasan adalah presentasi karya pop up book dari setiap guru peserta pelatihan kepada peserta lain.

\section{Tahap Penerapan}

Kegiatan pada tahap ini adalah guru menerapkan pop up book Mace yang telah dibuat sebagai media pembelajaran pada anak autis di SLB Negeri Anim Ha.

Untuk mengukur ketercapaian mitra dalam kegiatan pendampingan, maka digunakan instrumen berupa angket ketercapaian mitra untuk mengukur sampai sejauh mana peningkatan pengetahuan mitra setelah mengikuti setiap tahapan kegiatan. Target ketercapaian tersebut disajikan pada Tabel 1 berikut. 
Tabel 1. Target Ketercapaian Setiap Tahapan Kegiatan

\begin{tabular}{|c|c|}
\hline Pengenalan pop up book Mace & $\begin{array}{l}75 \% \text { guru memahami pengertian, } \\
\text { manfaat dan kelebihan pop up book } \\
\text { Mace }\end{array}$ \\
\hline $\begin{array}{l}\text { Memilih dan merancang konten pop up } \\
\text { book Mace }\end{array}$ & $\begin{array}{l}75 \% \text { guru mampu memilih dan } \\
\text { merancang konten pop up book Mace } \\
\text { meliputi konten bahasa, sains dan } \\
\text { matematika }\end{array}$ \\
\hline Mendesain sketsa pop up book Mace & $\begin{array}{l}75 \% \text { guru mampu mendesain sketsa } \\
\text { pop up book Mace }\end{array}$ \\
\hline $\begin{array}{l}\text { Mendesain karakter pada konten pop } \\
\text { up book Mace }\end{array}$ & $\begin{array}{l}75 \% \text { guru mampu mendesain karakter } \\
\text { pada konten pop up book Mace }\end{array}$ \\
\hline Menyusun pop up book Mace & $\begin{array}{l}75 \% \text { guru mampu menyusun pop up } \\
\text { book Mace }\end{array}$ \\
\hline $\begin{array}{l}\text { Mempresentasikan dengan baik karya } \\
\text { pop up book Mace }\end{array}$ & $\begin{array}{l}75 \% \text { guru mampu mempresentasikan } \\
\text { dengan baik pop up book Mace masing- } \\
\text { masing }\end{array}$ \\
\hline $\begin{array}{l}\text { Menerapkan pop up book Mace pada } \\
\text { siswa autisme }\end{array}$ & $\begin{array}{l}75 \% \text { siswa autis mengalami } \\
\text { peningkatan kemampuan literasi }\end{array}$ \\
\hline
\end{tabular}

\section{Hasil dan Pembahasan}

Sebelum kegiatan pendampingan dilakukan, tim pelaksana melakukan pretest untuk mengetahui sampai sejauh mana tingkat pengetahuan mitra sebelum dilakukan kegiatan pendampingan. Setelah kegiatan selesai dilakukan posttest untuk mengetahui keadaan akhir mitra. Ketercapaian mitra dilihat dari tujuh sub kegiatan pokok yang mengukur seberapa besar peningkatan pengetahuan dan banyaknya mitra yang mengalami peningkatan yang ditunjukkan dalam persentase jumlah.

\section{Pengenalan Pop Up Book Mace}

Pada tahap ini peserta diharapkan dapat memahami pengertian, manfaat dan kelebihan Pop Up Book Mace. Tim menjelaskan dan memeragakan berbagai macam bentuk-bentuk dasar pop up disertai demonstrasi dilanjutkan dengan praktik membuat dan menanam pada simulasi storyboard berupa kertas buffalo. Hasil capaian peserta pada tahap ini diukur dan selanjutnya ditunjukkan menggunakan grafik pada Gambar 2 berikut. 


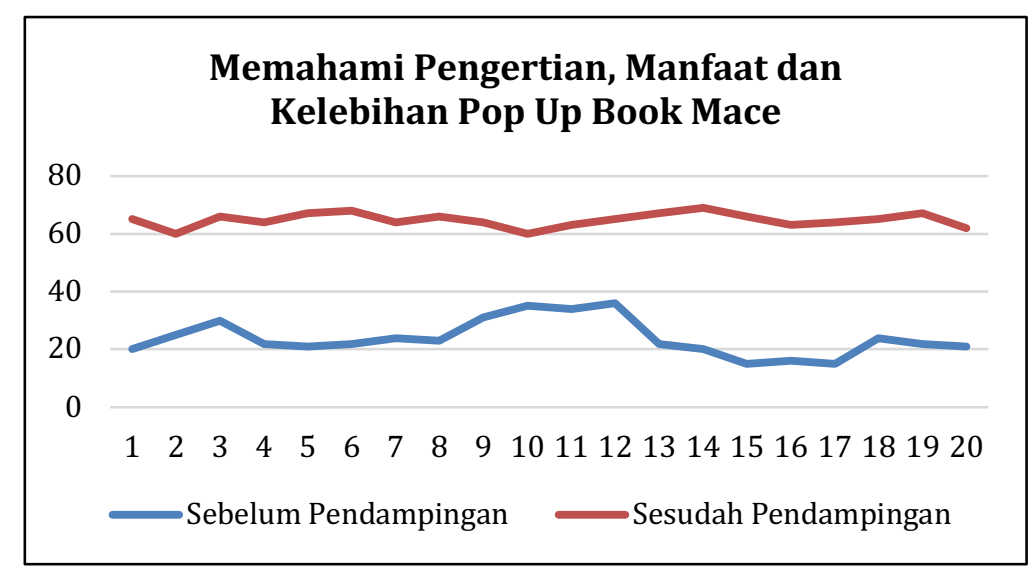

Gambar 2. Grafik Peningkatan Mitra dalam memahami pengertian, manfaat dan kelebihan Pop Up Book Mace
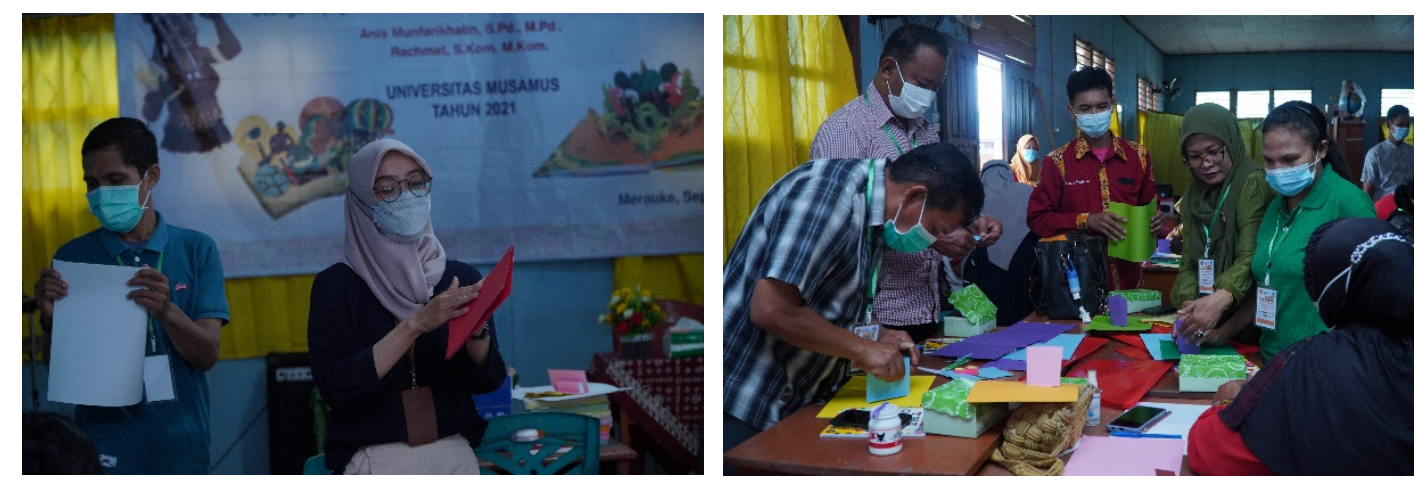

Gambar 3. Tim Memeragakan bentuk dasar dan peserta mempraktekkan langsung

Berdasarkan hasil capaian kegiatan pada tahap pengenalan diperoleh sebesar $58 \%$ peserta mengalami peningkatan pengetahuannya. Dari hasil pretest rata-rata nilai pengetahuan peserta sebesar 23,9 sedangkan posstest mangalami peningkatan sebesar 64,75 . Dari hasil pengamatan tim, peserta sangat antusias dalam mempraktekkan bentukbentuk dasar yang kemudian ditanam di storyboard.

\section{Memilih dan Merancang Konten Pop Up Book Mace}

Sebelum dibuat, peserta merancang konten terlebih dahulu, dengan memilih konten yang peserta minati yaitu literasi bahasa, literasi numerasi dan literasi sains. Pada tahap ini konten yang dipilih disarankan untuk disesuaikan dengan mata pelajaran dan jenjang yang diampu oleh peserta. Setelah konten ditentukan langkah selanjutnya adalah membuat rancangan desain pada kertas. Hasil pretest pada tahap ini sebesar 18,15 sedangkan hasil posttest sebasar 65,7. Presentase peningkatan pengetahuan peserta pada tahap ini sebesar 68\% yang disajikan pada Gambar 4. 


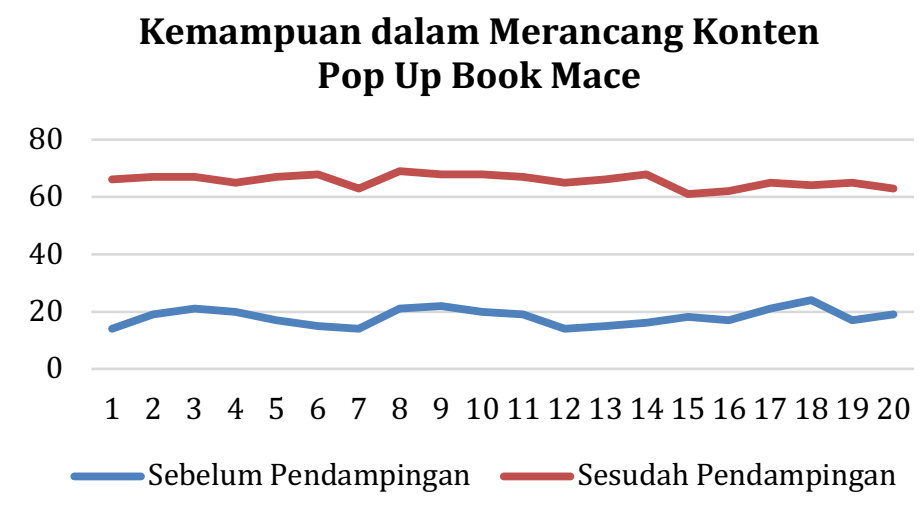

Gambar 4. Grafik Peningkatan Mitra dalam merancang konten Pop Up Book Mace
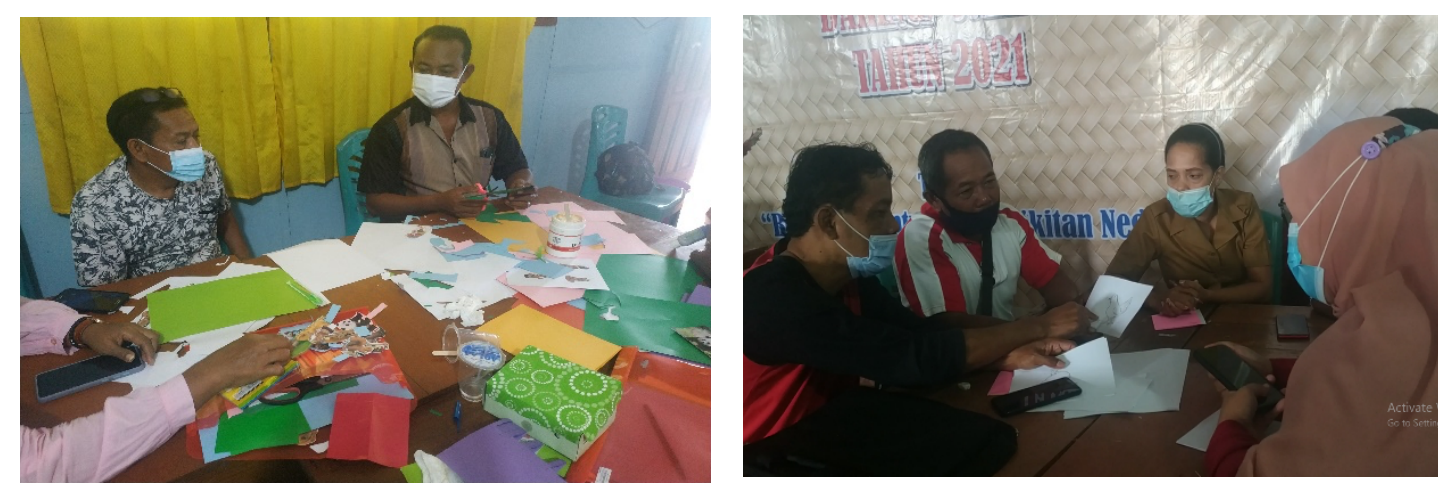

Gambar 5. Peserta merancang konten pop up yang akan dibuat

\section{Mendesain Sketsa Pop Up Book Mace}

Konten literasi yang sudah dibuat dan ditetapkan oleh masing-masing kelompok kemudian dibuat sketsa pada kertas untuk masing-masing halaman meliputi sketsa penempatan karakter dan objek-objek yang akan ditanam, dan alur cerita maupun keterangan yang akan disampaikan oleh karakter utama (Mace) pada tiap halaman. Capaian peserta pada tahap ini ditunjukkan pada gambar 1.5 berupa diagram hasil pretest dan posttest peserta pendampingan.

\section{Kemampuan dalam Mendesain Sketsa Pop Up Book Mace}

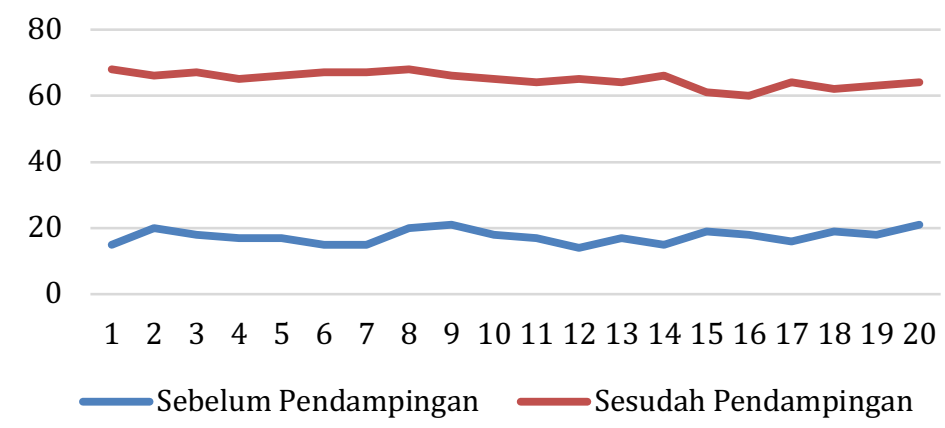

Gambar 6. Grafik Peningkatan Peserta dalam Mendesain Sketsa Pop Up Book Mace 

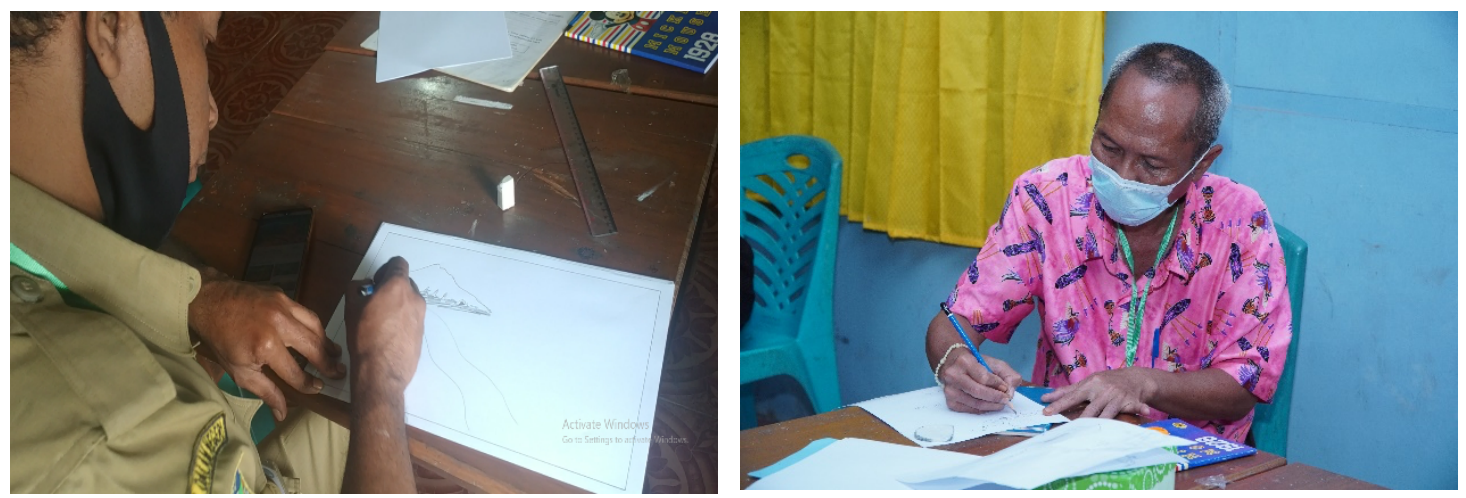

Gambar 7. Peserta mendesain sketsa Pop Up Book Mace

\section{Mendesain Karakter pada Konten Pop Up Book Mace}

Tahap keempat yaitu peserta mendesain karakter pada pop up book Mace. Banyak kendala yang dihadapi pada tahapan ini, sehingga untuk menentukan karakter utama diperlukan jasa desain illustrator untuk mempermudah peserta, dan mencari objek-objek pendukung yang bersumber dari internet.

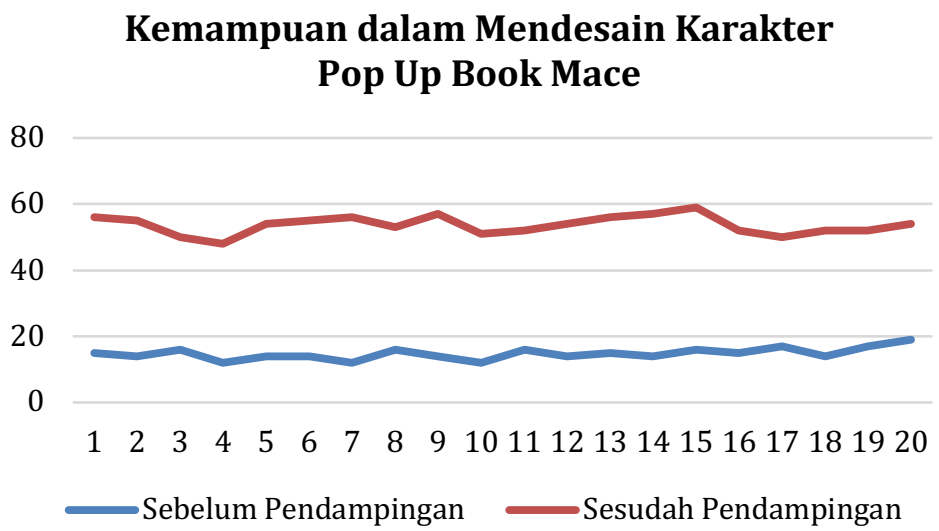

Gambar 8. Grafik Peningkatan Peserta dalam Mendesain Karakter Pop Up Book Mace
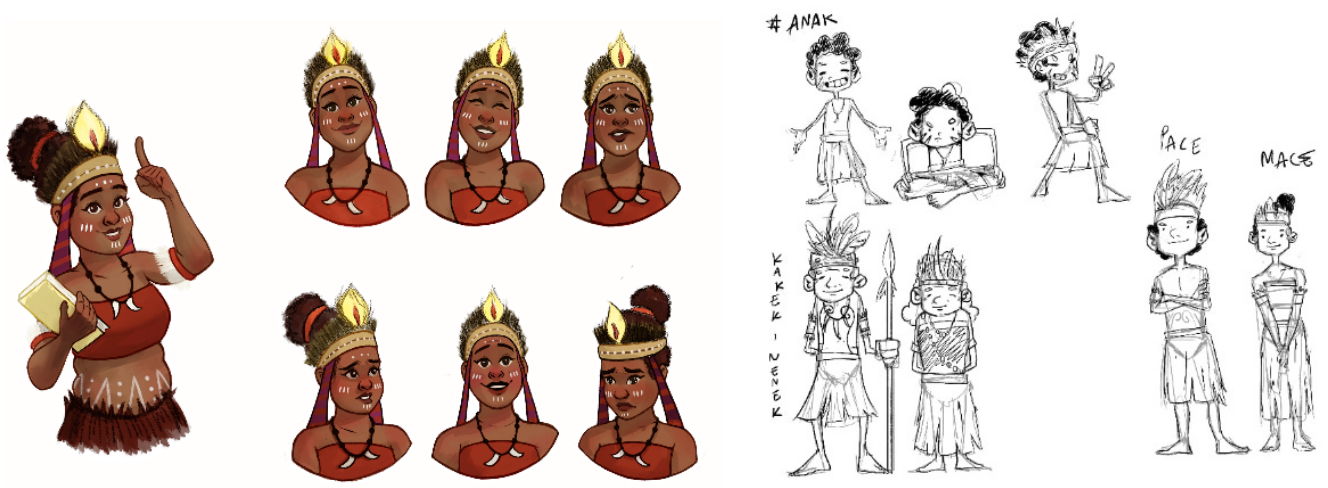

Gambar 9. Desain Karakter Pop Up Book Mace 
Kemampuan peserta dalam mendesain karakter disajikan pada gambar 1.6 yang menunjukkan rata-rata peserta mengalami peningkatan pengetahuan dalam tahapan ini sebanyak 56\%, dengan rata-rata hasil prestest sebesar 14,8 sedangkan posttest 53,65.

\section{Kemampuan dalam Menyusun Pop Up Book Mace}

Tahap kelima yaitu menyusun pop up book Mace yang meliputi kegiatan memotong, dan menempel pada storyboard yang telah ditentukan sebelumnya. Hal yang perlu diperhatikan dalam menyusun adalah kerapihan, ketelitian dan kesesuaian dalam mengaplikasikan bentuk-bentuk dasar dalam menempel. Kesalahan dalam menempel akan mengakibatkan pop up book tidak dapat tertutup dengan sempurna sehingga bentuknya akan menjadi tidak beraturan.

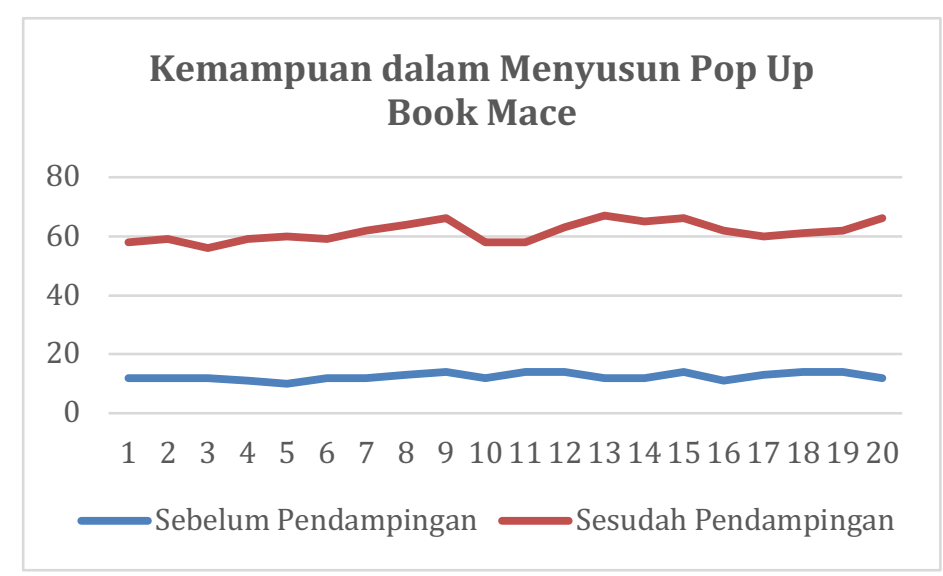

Gambar 10. Grafik Peningkatan Peserta dalam Mendesain Karakter Pop Up Book Mace

Berdasarkan grafik pada gambar 1.5 kemampuan peserta dalam menyusun pop up book Mace mengalami peningkatan dan rata-rata peningkatan sebesar $70 \%$. Nilai sebelum pendampingan sebesar 12,5 dan setelah pendampingan sebesar 61,55 .
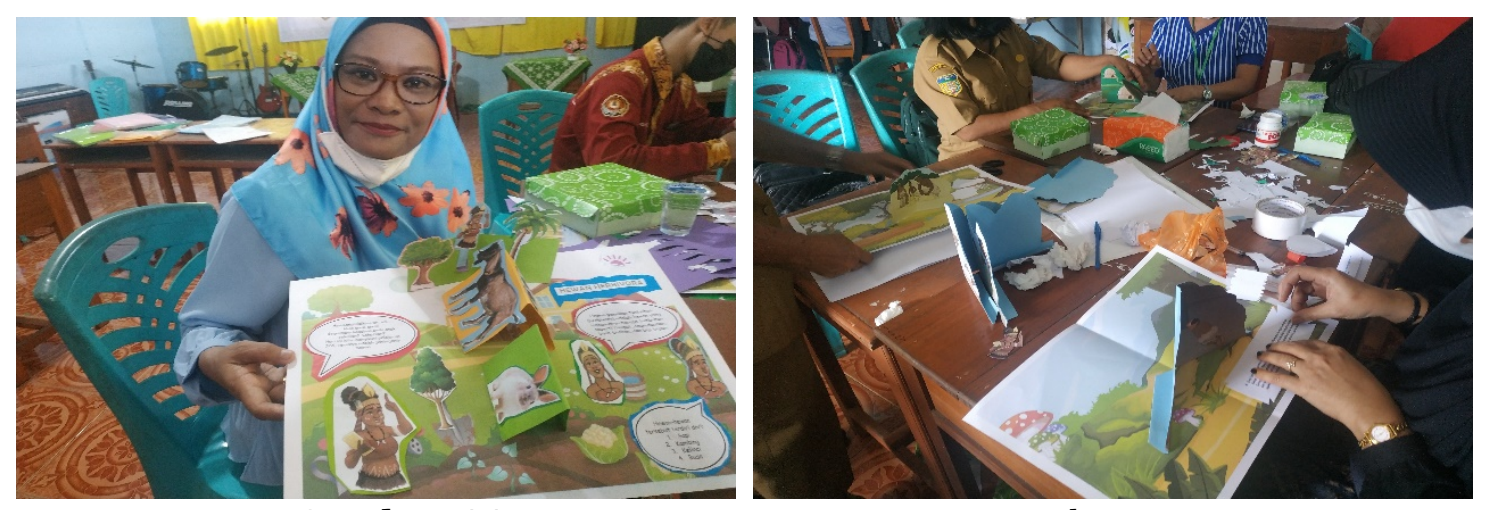

Gambar 11. Peserta Menyusun Pop Up Book Mace

\section{Mempresentasikan Pop Up Book Mace}

Tahapan kegiatan selanjutnya yaitu mempresentasikan pop up book Mace kepada peserta lainnya. Pop Up Book yang telah selesai dibuat kemudian dipresentasikan dan dijelaskan mulai dari konsep, tahapan penyusunan, dan tema yang dipilih. 


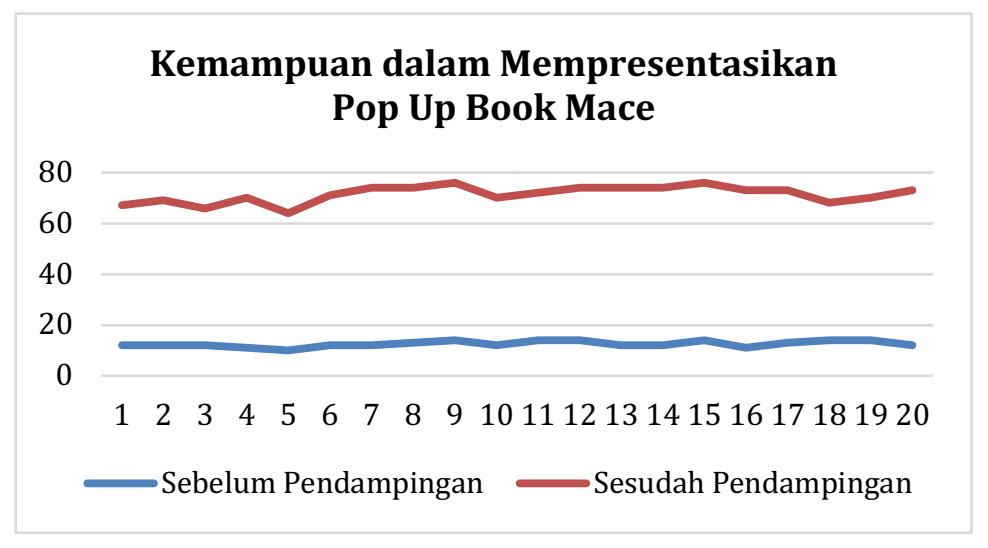

Gambar 12. Grafik Kemampuan Peserta dalam Menyusun Pop Up Book Mace
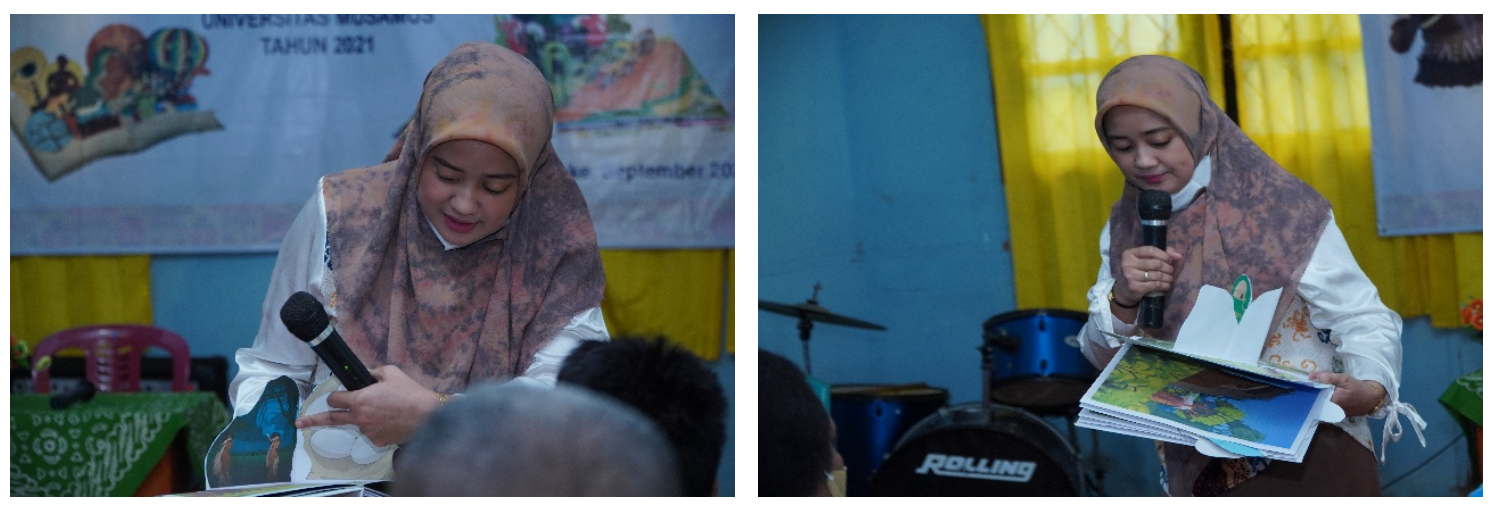

Gambar 13. Peserta Mempresentasikan Pop Up Book Mace

Peningkatan pengetahuan pesera dalam menyusun pop up book Mace ditunjukkan pada gambar 13 dengan persentase rata-rata peningkatan peserta sebesar $66 \%$ dengan nilai pretest 12,5 dan posttest 58,9 .

\section{Menerapkan Pop Up Book Mace pada Siswa Autisme}

Kegiatan akhir adalah menerapkan Pop Up Book Mace pada siswa autisme. Pembelajaran bagi siswa berkebutuhan khusus autisme tidak bisa diterapkan secara klasikal, karena mereka cenderung kesulitan untuk fokus terhadap benda. Pengetahuan peserta dalam mempresentasikan ditunjukkan pada hasil pretest dengan skor 11 dan posttest sebesar 58. Persentase rata-rata peningkatan pengetahuan mitra sebesar $67 \%$ yang berarti mitra mampu menerapkan dengan baik Pop Up Book yang telah dibuat kepada siswa autisme.

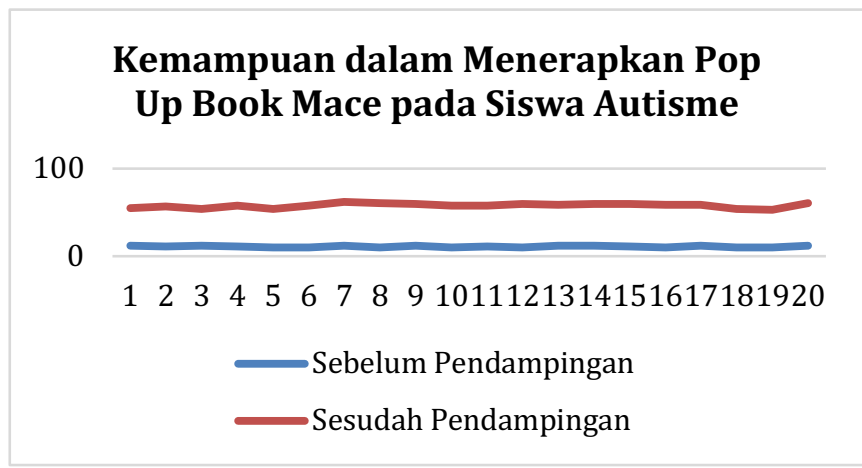

Gambar 14. Grafik Kemampuan Peserta dalam Menerapkan Pop Up Book Mace pada Siswa Autisme 

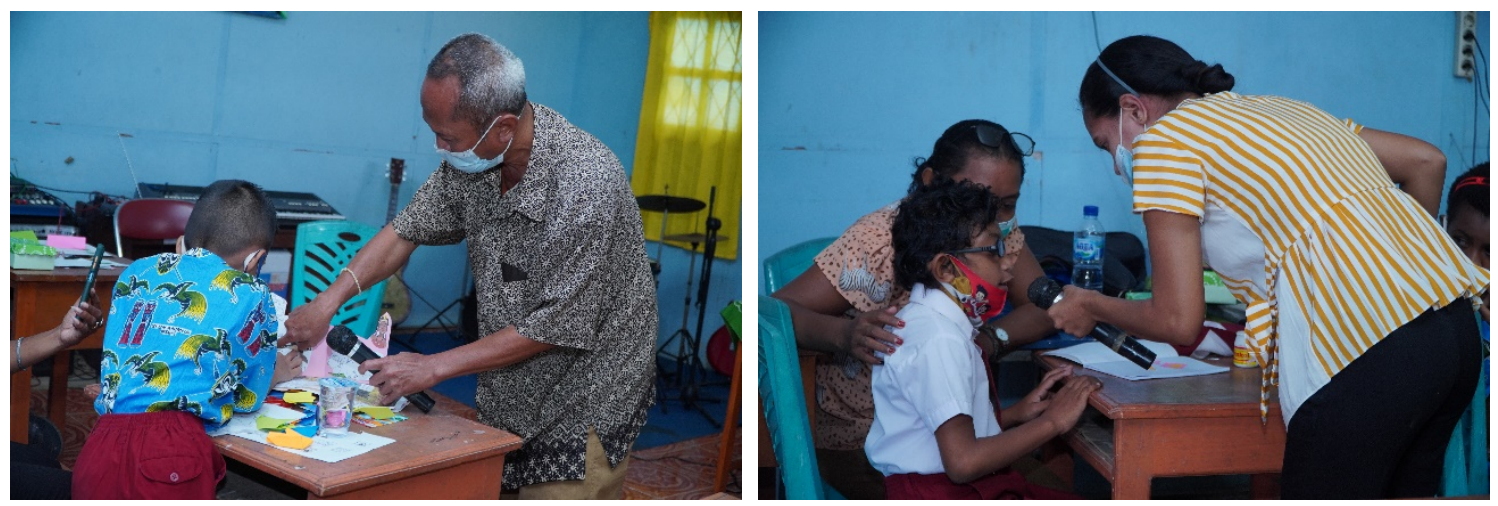

Gambar 15. Peserta Menerapkan Pop Up Book Mace pada Siswa Autisme

Kegiatan pengabdian kepada masyarakat dalam bentuk pendampingan pembuatan Pop Up Book Mace untuk meningkatkan kemampuan literasi siswa autisme dinilai sangat efektif. Siswa autisme yang cenderung kurang fokus, hiperaktif dan mudah bosan akan terbantu dalam memahami dan mengerti materi pembelajaran yang akan disampaikan. (Damarratih, Nurzulifa, Hastiningrum, \& G, 2019)mengemukakan bahwa Pop Up Book merupakan media yang inovatif, sederhana dan fungsional bagi siswa untuk membantu memahami materi untuk mencapai kesetaraan kognitif dan psikomotorik bagi siswa SLB. Hasil kegiatan pendampingan sebanyak tujuh kegiatan pokok menunjukkan peningkatan pengetahuan peserta dengan rata-rata peningkatan sebesar 65\%. Sependapat dengan (Nazaruddin \& Efendi, 2018) bahwa Pop Up Book dapat memberikan visualisasi yang menarik, dengan media Pop Up Book penyampaian cerita akan lebih mudah dimengerti dengan kejutan setiap halamannya. Budaya literasi juga diharapkan akan menjadi pembiasaan khsuusnya bagi siswa berkebutuhan khusus di SLB.

\section{Kesimpulan}

Kesimpulan dari kegiatan pendampingan ini adalah adanya peningkatan pengetahuan peserta dalam semua kegiatan pokok yang telah dilakukan. Keterlibatan peserta secara kooperatif dan aktif dinilai memberikan pengaruh yang besar atas ketercapaian yang maksimal dari setiap kegiatan. Produk akhir berupa Pop Up Book Mace yang terdiri dari konten literasi numerasi, sains dan bahasa yang siap digunakan untuk diterapkan dalam pembelajaran maupun sebagai produk awal jika Pop Up Book Mace dikembangkan lebih lanjut. Untuk keberlanjutan program maka dibentuk tim pengembang Pop Up Book di SLB Negeri Anim Ha sehingga diharapkan akan ada produk inovasi dari keberlanjutan program. 


\section{Ucapan Terimakasih}

Penulis mengucapakan terimaksih kepada DRPM Kementerian Pendidikan dan Kebudayaan atas dukungan pendanaan pada skim Pengabdian Kemitraan Masyarakat (PPM) Tahun 2021.

\section{Referensi}

Damarratih, R., Nurzulifa, S., Hastiningrum, D., \& G, N. I. D. (2019). Math Pop Up Comic Book : Media Pembelajaran Matematika Untuk Siswa Penderita Autisme. PRISMA, Prosiding Seminar Nasional Matematika https://journal.unnes.ac.id/sju/index.php/prisma/ISSN 2613-9189 Math, 2(2), 206219.

Depa Nursita, Lukman Hamid, N. N. (2020). Media Flash Card Untuk Meningkatkan Kemampuan Komunikasi Ekspresif Pada Anak Dengan Autisme Di Pendidikan Anak Usia Dini. Jurnal Keislaman dan Pendidikan, VOL. 1 NO.

Martono, K. T., Eridani, D., \& Isabella, D. I. S. (2020). User experience pada Implementasi Virtual Reality sebagai Media Pembelajaran Anak Pengidap Autisme. Jurnal Politeknik Caltex Riau, 6(1), 1-11.

Maulana, A., \& Rahayu, S. (2020). Rancang Bangun Aplikasi Panduan Cara Membuat Identitas Diri Untuk Penyandang Autis. Jurnal Algoritma, 17(1), 1-7. https://doi.org/10.33364/algoritma/v.17-1.1

Nazaruddin, M. A., \& Efendi, M. (2018). The Book of Pop Up Augmented Reality to Increase Focus and Object Recognition Capabilities for Children with Autism. Journal of ICSAR, 2(1), 9-14. https://doi.org/10.17977/um005v2i12018p009

Winarno, F. G. (2013). Autisme dan Peran Pangan. Gramedia Pustaka Utama.

Yuliani, R. (2020). Pola Komunikasi Guru Pada Siswa Anak Autis Di Sekolah Luar Biasa (Slb) Mitra Iswara Kabupaten Tasikmalaya. Metacommunication: Journal of Communication Studies, 5(2), 168. https://doi.org/10.20527/mc.v5i2.8807 